\title{
Iron fortification of shrikhand using Murraya koenigii leaves extract
}

\author{
Alan Jerish J' ${ }^{1}$ K S Gnanalaksshmi ${ }^{1}$, K Vijaya Rani ${ }^{2}$ and I Manikkavasagan ${ }^{1}$
}

Received: 31 July 2019 / Accepted: 15 October 2019 / Published online: 27 February 2020

(c) Indian Dairy Association (India) 2020

\begin{abstract}
In the present study, a novel shrikhand enriched with vitamin $\mathrm{C}$ and iron was developed using curry leaves extract. Encapsulation, which is the latest trend in delivering the phytochemicals through food products has increased the acceptability of the product. The treatment $\mathrm{S}_{3}$ which had the curry leaves extract of highest concentration $3: 10 \mathrm{~W} / \mathrm{V}$ had a good score on sensory evaluation due to the wall material - sodium alginate which acted as a barrier between the product and the extract without influencing the acceptability of shrikhand with its strong off-flavor. The nutrient composition of iron-fortified shrikhand for energy, carbohydrate, fat, protein, moisture and ash was $199.65 \mathrm{Kcal}, 23.67 \mathrm{~g}, 9.62 \mathrm{~g}, 4.55 \mathrm{~g}, 61.26 \mathrm{~g}$ and $0.85 \mathrm{~g}$ per $100 \mathrm{~g}$ of the product, respective vitamin $\mathrm{C}$ and iron content of product was of $18.86 \mathrm{mg} / 100 \mathrm{~g}$ and $2.26 \mathrm{mg} / 100 \mathrm{~g}$.
\end{abstract}

Keywords: Curry leaves, Encapsulation, Iron, Shrikhand, Vitamin C

\section{Introduction}

Food can be defined as a substance that is composed of macronutrients - carbohydrates, proteins and fat and the necessary micronutrients including vitamins and minerals that are vital for an organism to sustain itself (The Editors of

${ }^{1}$ College of Food and Dairy Technology, Tamil Nadu Veterinary and Animal Sciences University, Chennai - 600052

${ }^{2}$ Madras Veterinary College, Tamil Nadu Veterinary and Animal Sciences University, Chennai - 600052

Alan Jerish J.( $\square)$

College of Food and Dairy Technology,

Tamil Nadu Veterinary and Animal Sciences University,

Chennai - 600 052. Tamil Nadu, India.

Email: alanjerish@gmail.com

Mobile: +919500972362
Encyclopædia Britannica 2018). Fruits and vegetables have long been considered as a major source of micronutrients. However, dairy products have now been evidenced to possess several minerals and trace elements that contribute to a healthy system and has been included in several nutritional food guidelines (Painter et al. 2002). Indian ayurvedic scripts since $6000 \mathrm{BC}$ refers to the consumption of fermented milk products (Brothwell and Brothwell ,1998). Consumption of fermented products by people around the globe increases especially during the hot climate (Nicholls et al.1939). These products are mainly desirable due to their high acidity, which keeps the product away from harmful pathogens. Since milk contains a reasonably high nutritional quality and has higher bioavailability, milk has conventionally been recommended as a nutritional food for daily consumption (Claeys et al. 2013). On the other hand, milk lacks some essential minerals and vitamins such as iron and vitamin C (Fernandez, 2017).

Shrikhand is a fermented dairy product of Indian origin and the name is derived from the Sanskrit word 'Shikharani' that refers to a delicacy prepared with curd, fruits, nuts, sweeteners, and flavoring agents. Shrikhand is used as a dessert in several places in India including Gujarat, Maharastra, Karnataka and certain parts of South India (Aneja et al. 2002). The macronutrients contained in Shrikhand comprises of $10 \%$ fats, $78 \%$ carbohydrates and $11.5 \%$ proteins and has a high water (moisture) content of $39 \%$ with an acidic pH range of 4.2 to 4.4 (Kulkarni et al. 2006; Boghra et al. 2000)

Murraya koenigii (curry leaves) have always been an integral part of the Indian Ayurvedic system of medicine and have been reported as an appetizer, carminative, anti-inflammatory agent, antibacterial agent (Husain 1992). Dinesh et al. (2015) evaluated the ascorbic acid content in selected Indian spices including curry leaves. The findings reported that curry leaves have 22.53 $\mathrm{mg} / 100 \mathrm{~g}$ of ascorbic acid present in them. Singh et al. (2014) compared the nutrition and mineral profile of curry leaves in fresh and dried form. It was observed to be $0.93 \mathrm{mg} / 100 \mathrm{~g}$ of iron when it is fresh and $12 \mathrm{mg} / 100 \mathrm{~g}$ when it is dehydrated. Murraya koenigii, in Indian dialects, curry leaves or karipatta belongs to the family Rutaceae that represents more than 150 genera and 1600 species (Satyavati et al. 1987). As it has a high nutrition 


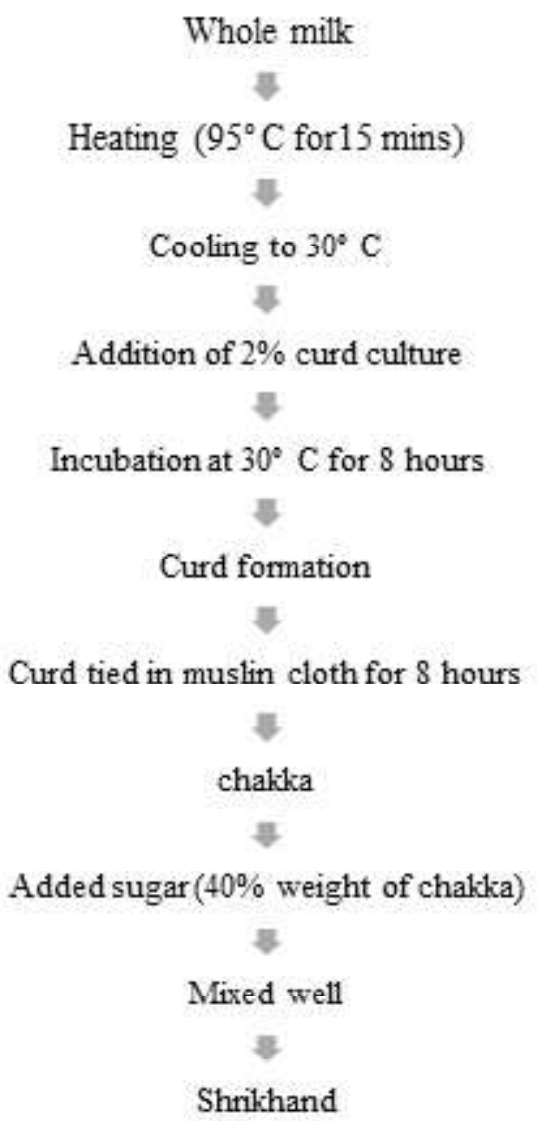

Fig. 1 Production of shrikhand (flow chart)

profile it can be used as an ideal supplement to fermented dairy products.

Encapsulation is defined as a technique that used to protect a component from external environment. The protective layer serves as a barrier between the encapsulated component and environment without altering the nature of the component. Sodium alginate is a commonly used material that is most compatible with all kinds of encapsulation. Usually, they are used as a combination with other components for the encapsulation of probiotic cultures (Burgainet al. 2011) and since it can absorb water and facilitates easy manipulation, sodium alginate is used as a material for encapsulation in the food industry (Goh et al. 2012). It is known for its gelling, stabilizing and thickening properties. So, in the present study, it is intended to encapsulate the curry leaves extract using sodium alginate and is added to the dairy product.

\section{Materials and Methods}

\section{Preparation of curry leaves powder}

The methods used by Das et al. (2011) with slight modifications was followed. The twigs were removed and the leaves alone were collected, washed in distilled water and dried in a solar dryer at $50-60^{\circ} \mathrm{C}$ until the moisture got removed. Once the moisture was completely removed, they were pulverized to a fine powder with a sieve and stored in a desiccator for further use.

\section{Preparation of curry leaves extract}

Methods used by El-Amin et al. (2013) with slight modifications was followed. The powdered sample was taken in a beaker with different solvents with a $1: 10 ; 2: 10$ and $3: 10(\mathrm{~W} / \mathrm{V})$ ratio and subjected to continuous stirring at room temperature with a magnetic stirrer for 6 hours. Then the extract was filtered using Whatman filter paper, sealed and stored in the refrigerator for further use.

\section{Preparation of shrikhand}

The method followed by Swapna and Chavannavar (2013) was adapted for the preparation of shrikhand shown in Figure 1 .

\section{Preparation of alginate and gelling solution}

The alginate and gelling solution were prepared based on the protocol by Valenzuela et al. (2014) with slight modifications. $2 \mathrm{~g}$ 
of sodium alginate powder (food grade) was dissolved in $100 \mathrm{~mL}$ of distilled water and stirred continuously for $30 \mathrm{mins}$ at room temperature to produce $2 \%(\mathrm{~W} / \mathrm{V})$ alginate solution. The gelling solution was prepared by dissolving $2.8 \mathrm{~g}$ of calcium chloride in $40 \mathrm{~mL}$ of distilled water.

\section{Preparation of alginate encapsulates with curry leaves extract}

The aqueous curry leaf extract was added to $2 \%$ food grade sodium alginate powder. It was mixed completely with a magnetic stirrer. The extract was loaded into a syringe and dripped down into the calcium chloride bath (gelling solution). The beads formed were washed and stored at $4^{\circ} \mathrm{C}$ for future use.

\section{Standardization and optimization of the curry leaves encapsulates in shrikhand}

Plain shrikhand was prepared. The curry leaves extracts that were extracted with different concentrations and encapsulated with sodium alginate were added.

The experimental model is illustrated below in Table 1.

\section{Sensory evaluation of the product}

Sensory evaluation of the product was carried out by trained judges on a 9-point Hedonic scale with sensory attributes viz. taste, odor, mouthfeel, color, and overall acceptability at the College of Food and Dairy Technology, Chennai - 52.

\section{Proximate analysis of the product}

The moisture protein, fat, and ash were determined by the method suggested in FSSAI manual (2016), sections 14 and 15 (Milk and milk products). The crude fiber content was determined by the method suggested in AOAC $20^{\text {th }}$ edition (2016) 926.09. The Nitrogen Free Extract (NFE) and energy were calculated by the difference method suggested in ISI: SP: 18 part XI, (1989) provided below.

$$
\begin{gathered}
\% \text { carbohydrates }(\mathrm{NFE})=\{100-(\text { Moisture }+ \text { Total ash }+ \text { Total } \\
\text { protein }+ \text { Fat })\} \\
\text { Energy }=\{(\text { protein } \times 4)+(\text { carbohydrate } x 4)+(\text { fat } x 9)\}
\end{gathered}
$$

\begin{tabular}{|c|c|c|}
\hline Product & Experimental model & Code \\
\hline \multirow[t]{3}{*}{ Shrikhand } & Plain shrikhand (Control) & $\mathrm{S}_{0}$ \\
\hline & Plain shrikhand ${ }^{*}+$ alginate encapsulates ${ }^{* *}$ with $(1: 10) \mathrm{W} / \mathrm{V}$ of curry leaves extract & $\mathrm{S}_{1}$ \\
\hline & Plain shrikhand* + alginate encapsulates ${ }^{* *}$ with $(3: 10) \mathrm{W} / \mathrm{V}$ of curry leaves extract & $\mathrm{S}_{3}$ \\
\hline
\end{tabular}

\section{Analysis of vitamin $\mathrm{C}$ and iron}

Table 1 Experimental model for the product

$\left(^{*}\right) 95 \mathrm{~g}$ of the dairy product

(**) $5 \mathrm{~g}$ of the encapsulates as a topping

The method suggested in AOAC $20^{\text {th }}$ edition (2016) 926.09 was followed for the estimation of iron as $(\mathrm{Fe})$ iron and the procedures recommended in FSSAI manual (2016) 2 (Fruits and vegetable product) were followed for the estimation of ascorbic acid (vitamin C).

\section{Statistical analysis}

The data collected on various parameters were statistically analyzed using IBM SPSS version 23. One way Analysis of variance (ANOVA) at 5\% level of significance was used to evaluate all the results as per the standard method listed in the procedure of Snedecore and Cochran, (1980).

\section{Results and Discussion}

\section{Optimizing the concentration of curry leaves extract encapsulated in alginate encapsulates on shrikhand}

The mean \pm SE of taste, odour, mouth feel, colour and overall acceptability scores of shrikhand topped with alginate encapsulates viz. $\mathrm{S}_{0}, \mathrm{~S}_{1}, \mathrm{~S}_{2}$ and $\mathrm{S}_{3}$ has been represented in Table 2.

In the present study, a significant $(\mathrm{P}<0.05)$ difference occurred in sensory attributes between the control $\left(\mathrm{S}_{0}\right)$ and all the other treatments viz. $\mathrm{S}_{1}, \mathrm{~S}_{2}$ and $\mathrm{S}_{3}$.

The acceptability of the shrikhand topped with alginate encapsulates is measured in terms of sensory attributes such as taste, odour, mouthfeel, colour, and overall acceptability.

Sensory evaluation of shrikhand topped with alginate encapsulates was carried out separately for each treatment $\left(\mathrm{S}_{1}\right.$, $\mathrm{S}_{2}$, and $\mathrm{S}_{3}$ ) with 1:10, 2:10 and 3:10 W/V of curry leaves extract respectively encapsulated with alginate as a wall material and with control $\mathrm{S}_{0}$ (plain shrikhand without the encapsulates). The optimization of the product was predicted based on the sensory score given by the judges. Shrikhand topped with alginate encapsulates of different concentrations of curry leaves extract selected from each treatment was evaluated based on the sensory attributes to select the best one.

Statistical analysis revealed there is a highly significant ( $\mathrm{P}$ d" 0.01) difference concerning taste, odour, colour and overall 
acceptability and also a significant $(0.01<\mathrm{P} \leq 0.05)$ difference with regard to mouthfeel between the treatments.

The order of sensory attribute test was identified as $\left(\mathrm{S}_{0}>\mathrm{S}_{3}>\mathrm{S}_{2}>\mathrm{S}_{1}\right)$ for taste, $\left(\mathrm{S}_{0}>\mathrm{S}_{2}>\mathrm{S}_{3}>\mathrm{S}_{1}\right)$ odour, $\left(\mathrm{S}_{0}>\mathrm{S}_{1}>\mathrm{S}_{2}>\mathrm{S}_{3}\right)$ mouthfeel, $\left(\mathrm{S}_{0}>\mathrm{S}_{3}>\mathrm{S}_{2}>\mathrm{S}_{1}\right)$ colour and $\left(\mathrm{S}_{0}>\mathrm{S}_{3}>\mathrm{S}_{1}>\mathrm{S}_{2}\right)$ overall acceptability.

The treatment $\mathrm{S}_{3}$ was significantly superior over other treatments $\left(\mathrm{S}_{1}, \mathrm{~S}_{2}\right)$. The shrikhand $\mathrm{S}_{3}$ topped with alginate encapsulates with $3: 10 \mathrm{~W} / \mathrm{V}$ of curry leaves extract had better overall acceptability (7.80) following the plain shrikhand $\mathrm{S}_{0}$ (8.39) without encapsulates. The results indicate that the addition of alginate encapsulates over shrikhand has influenced the sensory scores with respect to taste, odour, mouth feel, colour and overall acceptability.

\section{Proximate analysis of the product}

Table 3 shows the comparison of mean \pm SE proximate analysis of control $\left(\mathrm{S}_{0}\right)$ and shrikhand topped with alginate encapsulates $\left(\mathrm{S}_{3}\right)$. The results obtained for energy, carbohydrate, fat, protein, moisture, ash and crude fiber for plain shrikhand $\left(\mathrm{S}_{0}\right)$ and shrikhand topped with alginate encapsulates $\left(\mathrm{S}_{3}\right)$ are as follows, energy $(212.50 \pm 0.49)$ and $(199.65 \pm 0.27)$, carbohydrate $(26.96 \pm$ $0.12)$ and $(23.67 \pm 0.06)$, fat $(9.61 \pm 0.007)$ and $(9.62 \pm 0.004)$, protein $(4.52 \pm 0.008)$ and $(4.55 \pm 0.008)$, moisture $(58.16 \pm 0.12)$ and $(61.26$ $\pm 0.06)$, ash $(0.82 \pm 0.003)$ and $(0.85 \pm 0.003)$. The crude fiber was found to be below the detection level in both $\mathrm{S}_{0}$ and $\mathrm{S}_{3}$.

On comparing the obtained figures of nutritional profile, the 0.03 $\mathrm{g}$ raise in protein on $\mathrm{S}_{3}$ may be due to the presence of curry

Table 2 Sensory analysis for shrikhand topped with alginate encapsulates encapsulated with curry leaves extract of different concentration $(\text { Mean } \pm \mathrm{SE})^{\circledR}$

\begin{tabular}{|c|c|c|c|c|c|}
\hline \multirow{2}{*}{$\begin{array}{l}\text { Sensory attributes } \\
\text { (9-point hedonic scale) }\end{array}$} & \multicolumn{5}{|c|}{ Concentration of alginate encapsulates topped in shrikhand } \\
\hline & $\overline{\mathrm{S}_{0}}$ & $\overline{S_{1}}$ & $\mathrm{~S}_{2}$ & $\mathrm{~S}_{3}$ & F value \\
\hline$\overline{\text { Taste }}$ & $8.57^{\mathrm{c}} \pm 0.10$ & $7.87^{a} \pm 0.08$ & $7.75^{\mathrm{a}} \pm 0.12$ & $8.00^{\mathrm{a}} \pm 0.17$ & $7.21^{* *}$ \\
\hline Odour & $8.29^{c} \pm 0.07$ & $7.45^{\mathrm{a}} \pm 0.17$ & $8.04^{\mathrm{bc}} \pm 0.18$ & $7.66^{\mathrm{ab}} \pm 0.15$ & $5.83^{* *}$ \\
\hline Mouth feel & $8.33^{c} \pm 0.15$ & $8.12^{\mathrm{bc}} \pm 0.22$ & $7.75^{\mathrm{ab}} \pm 0.12$ & $7.58^{\mathrm{a}} \pm 0.15$ & $4.15^{*}$ \\
\hline Colour & $8.41^{\mathrm{c}} \pm 0.12$ & $7.50^{\mathrm{a}} \pm 0.11$ & $7.50^{\mathrm{a}} \pm 0.14$ & $7.95^{\mathrm{b}} \pm 0.17$ & $9.68^{* *}$ \\
\hline Overall acceptability & $8.39^{b} \pm 0.04$ & $7.73^{\mathrm{a}} \pm 0.05$ & $7.76^{\mathrm{a}} \pm 0.04$ & $7.80^{\mathrm{a}} \pm 0.04$ & $33.99^{* *}$ \\
\hline
\end{tabular}

Data are presented in Mean $\pm \mathrm{SE}, \mathrm{n}=6$ (Different superscripts in a row differ significantly)

** - Highly Significant $(\mathrm{P} \leq 0.01)$

* - Significant $(0.01<\mathrm{P} \leq 0.05)$

NS - Not Significant $(\mathrm{P}>0.05)$

$\mathrm{S}_{0}$ - Plain shrikhand

$\mathrm{S}_{1}$ - Plain shrikhand $+5 \mathrm{~g}$ of $1: 10(\mathrm{~W} / \mathrm{V})$ alginate encapsulates

$\mathrm{S}_{2}$ - Plain shrikhand $+5 \mathrm{~g}$ of $2: 10(\mathrm{~W} / \mathrm{V})$ alginate encapsulates

$\mathrm{S}_{3}$ - Plain shrikhand $+5 \mathrm{~g}$ of $3: 10(\mathrm{~W} / \mathrm{V})$ alginate encapsulates

Table 3 Proximate analysis of product $(\text { Mean } \pm \mathrm{SE})^{@}$

\begin{tabular}{lllc}
\hline Parameter & Unit & $\mathrm{S}_{0}$ & $\mathrm{~S}_{3}$ \\
\hline Energy & $\mathrm{Kcal} / 100 \mathrm{~g}$ & $212.50 \pm 0.49$ & $199.65 \pm 0.27$ \\
Carbohydrate & $\mathrm{g} / 100 \mathrm{~g}$ & $26.96 \pm 0.12$ & $23.67 \pm 0.06$ \\
Fat & $\mathrm{g} / 100 \mathrm{~g}$ & $9.61 \pm 0.007$ & $9.62 \pm 0.004$ \\
Protein & $\mathrm{g} / 100 \mathrm{~g}$ & $4.52 \pm 0.008$ & $4.55 \pm 0.008$ \\
Moisture & $\mathrm{g} / 100 \mathrm{~g}$ & $58.16 \pm 0.12$ & $61.26 \pm 0.06$ \\
Ash & $\mathrm{g} / 100 \mathrm{~g}$ & $0.82 \pm 0.003$ & $0.85 \pm 0.003$ \\
Crude Fiber & $\mathrm{g} / 100 \mathrm{~g}$ & $\mathrm{BDL}$ & $\mathrm{BDL}$ \\
\hline
\end{tabular}

BDL - Below the Detection Level

Data are presented in Mean $\pm \mathrm{SE}, \mathrm{n}=6$

Table 4 Analysis of vitamin $\mathrm{C}$ and iron

\begin{tabular}{lllc}
\hline Parameter & Unit & $\mathrm{Y}_{0}$ & $\mathrm{Y}_{3}$ \\
\hline Vitamin C & $\mathrm{mg} / 100 \mathrm{~g}$ & $\mathrm{BDL}$ & $18.86 \pm 0.05$ \\
Iron & $\mathrm{mg} / 100 \mathrm{~g}$ & $\mathrm{BDL}$ & $2.26 \pm 0.01$ \\
\hline
\end{tabular}

BDL-Below the Detection Level

Data are presented in Mean $\pm \mathrm{SE}, \mathrm{n}=6$ 
leaves extracts on the encapsulates which has $11.8 \%$ of the protein in it (Zhang et al. 2011). The $0.01 \mathrm{~g}$ increase in fat in the product $\mathrm{S}_{3}$ may be due to the wall material (alginate) as reported by a previous study (Reyes-Tisnado et al. 2005) where $2.11 \mathrm{~g} / 100 \mathrm{~g}$ of fat was obtained post encapsulation. An increase in moisture content on product $\mathrm{S}_{3}$ was noticed due to the addition of encapsulates which hold the aqueous curry leaves extract. It may also be due to the addition of alginate beads which has $11.10 \%$ moisture as reported by (Reyes-Tisnado et al. 2005). Though there is an increase in the moisture content of product $\mathrm{S}_{3}$ there occurs a slight decrease in carbohydrate and energy content of the products compared to the plain shrikhand $\mathrm{S}_{0}$.

\section{Analysis of vitamin $\mathrm{C}$ and iron}

Table 4 shows the comparison of mean $\pm \mathrm{SE}$ vitamin $\mathrm{C}$ and iron of control $\left(\mathrm{S}_{0}\right)$ and shrikhand topped with alginate encapsulates $\left(\mathrm{S}_{3}\right)$.

The results obtained for the vitamin $\mathrm{C}$ and iron for plain shrikhand $\left(\mathrm{S}_{0}\right)$ and shrikhand topped with alginate encapsulates $\left(\mathrm{S}_{3}\right)$ are as follows - vitamin C (BDL and 18.86 \pm 0.005$)$ iron (BDL and 2.26 \pm $0.01)$ respectively.

On interpreting the obtained data on vitamin $\mathrm{C}$ and iron, iron and vitamin $\mathrm{C}$ were not detected in plain shrikhand ( $\mathrm{S} 0$ ) due to the commonly known fact that milk and milk products lack in vitamin $\mathrm{C}$ and iron (Fernandez, 2017).

On the other hand, the shrikhand topped with alginate encapsulates that has curry leaves extract shows a remarkable enrichment on its vitamin $\mathrm{C}$ and iron profile by increasing the content to $18.86 \pm 0.05 \mathrm{mg} / 100 \mathrm{~g}$ and $2.26 \pm 0.01 \mathrm{mg} / 100 \mathrm{~g}$ respectively. However, the vitamin $\mathrm{C}$ content was lower and the iron content was higher when compared to the findings of other researchers (Bahuguna and Vijayalakshmi, 2018). The iron content was slightly higher than that obtained by Ranjitha and Sudha (2016).

\section{Conclusions}

The curry leaves extract extracted with 3:10 W/V of curry leaves powder and encapsulated using alginate added to shrikhand $\left(\mathrm{S}_{3}\right)$ and found to be acceptable by sensory evaluation. Nutrition analysis on $\mathrm{S}_{0}$ and $\mathrm{S}_{3}$ was found to be good in all the parameters. The product topped with alginate encapsulates $\mathrm{S}_{3}$ was found to have an increased level of vitamin $\mathrm{C}$ and iron. From the present study, it is concluded that curry leaves extract is rich in vitamin $\mathrm{C}$ and iron and can be used in dairy products by encapsulating them which serves as a barrier between the product and the extract.

\section{Reference}

Aneja, RP, Mathur BN, Chandan RC, Banerjee AK (2002) Technology of Indian milk products: handbook on process technology modernization for professionals, entrepreneurs and scientists. Dairy India Year book.

Boghra VR, Mathur ON (2000) Physico-chemical status of major milk constituents and minerals at various stages of shrikhand preparation. J Food Sci Technol 7: 111-115

Brothwell DR, Brothwell P (1998) Food in antiquity: a survey of the diet of early peoples. 66. JHU Press

Burgain J, Gaiani C, Linder M, Scher J (2011) Encapsulation of probiotic living cells: From laboratory scale to industrial applications. J Food Eng 104: 467-483

Claeys, Wendie L, Sabine Cardoen, Georges Daube, Jan De Block, Koen Dewettinck, Katelijne Dierick, Lieven De Zutter (2013) Raw or heated cow milk consumption: review of risks and benefits. Food Control 1: 251-262.

Das AK, Rajkumar V, Dwivedi DK (2011) Antioxidant effect of curry leaf (Murraya koenigii) powder on quality of ground and cooked goat meat. Int Food Res J 18: 563-569

Dinesh B, Yadav B., Reddy RD, Padma AS, Sukumaran MK (2015) Determination of ascorbic acid content in some Indian spices. Int $\mathrm{J}$ Curr Microbiol Appl Sci 4: 864-868

El-Amin M, Virk P, Elobeid MA, Almarhoon ZM, Hassan ZK, Omer SA, Al-Olayan EM (2013) Anti-diabetic effect of Murraya koenigii (L) and Olea europaea (L) leaf extracts on streptozotocin induced diabetic rats. Pak J Pharm Sci 26: 359-365

Fernandez MA, Marette A (2017) Potential health benefits of combining yogurt and fruits based on their probiotic and prebiotic properties. Adv Nutr 8:155-164

Goh CH, Heng PWS, Chan LW (2012) Alginates as a useful natural polymer for microencapsulation and therapeutic applications. Carbohydr Polym 88: 1-12

Husain, Akhtar (1992) Dictionary of Ind Med Plants

Kulkarni Chandrashekhar, Nilesh Belsare, Ashish Lele (2006) Studies on shrikhand rheology. J Food Eng 74: 169-177

Nicholls L, Nlmalasuria A, Silva B De (1939) The preparation of fermented milk ("curds"). Ceylon J Sci Section D Med Sci 5: 17-20

Painter James, Rah Jee-Hyun, Lee Yeon-Kyung (2002) Comparison of International Food Guide Pictorial Representations. J Am Dietetic Assoc 102: 483-489

Reyes-Tisnado R, Hernandez-Carmona G, Rodriguez-Montesino E, Arvizu Higuera DL, Lopez-Gutierrez F (2005) Food grade alginates extracted from the giant kelp Macrocystis pyrifera at pilot-plant scale. Rev Invest Mar 26: 185-192

Satyavati GV, Gupta AK, Tandon N(1987) Medicinal Plants of India, vol. 2. Indian Council of Medical Research, New Delhi, India, pp. 289299.

SinghS, More PK, Mohan SM (2014) Curry leaves (Murraya koenigii Linn. Sprengal) - a mircale plant. Indian J Scientific Res 4: 46-52

Snedecor GW, Cochran WG (1989) Statistical methods, $8^{\text {th }}$ Edn. Ames: Iowa State Univ Press Iowa.

Swapna G, Chavannavar SV (2013) Shrikhand-Value added traditional dairy product. Int J Food Nutr Sci 2: 45-51

The Editors of Encyclopædia Britannica. 2018. "Food” In Encyclopædia Britannica. Encyclopædia Britannica, inc.

Zhang M, Hettiarachchy NS, Horax R, Kannan A, Praisoody A and Muhundan A (2011) Phytochemicals, antioxidant and antimicrobial activity of Hibiscus sabdariffa, Centella asiatica, Moringa oleifera and Murraya koenigii leaves. J Med Plants Res 5: 6672-6680 